\title{
PROFESSIONAL COMPETENCE AND THEIR TYPES
}

\author{
Zarnigor Shomahmatovna Shomahmatova
}

Master, Samarkand State University, Uzbekistan

\section{ABSTRACT}

This article explains the meaning of the concept of competence, the meanings of the word, professional, personal, spiritual-educational, special, universal and other types of competence. The essence of competence is based on the views of Western scholars. EvaldTerhart, Franz Weinert, Benjamin Bloom, and other scholars have commented on the elucidation of the concept of competence in scientific research.

KEYWORDS:- Competence, competence, professional, personal, spiritual-educational, special, universal personal experience, professional term, professional skill.

\section{INTRODUCTION}

As in other disciplines, modern concepts have emerged in the field of pedagogy. Such concepts include the term "competent". By the 1990s, the word began to be used extensively, including psychology, economics, and a number of other fields. Later, the term was used to refer to concepts such as competence and competence. First of all, let's talk about its lexical meaning. Competence is translated from Latin as "competentia", which means "one who knows well", "one who has experience", "achieves", "deserves", "deserves". Explanatory dictionaries of pedagogical terms explain that competence is knowledge in one field or another. In general, competence is the degree to which a set of acquired theoretical knowledge, skills, and competencies can be put into practice independently and creatively.
The concept of competence in pedagogy includes the following. Ability and skill to solve problems in the mentioned areas, as well as preparation for it are considered. The concept of educational competence links facto-categorical, methodological and volitional elements, including their application to a variety of topics. At its core include ability, will, and responsibility. According to another view, the theory of competence is based on the definition of competence by cognitive psychologist Franz Weinert. The concept of competence has advantages over older learning objectives, such as learning objectives, which are also seen in success scrutiny:

First, it is not about individual elements of knowledge or skills, but the coordinated application of different individual services based on a problem that is new to the student. 
CURRENT RESEARCH JOURNAL OF PEDAGOGICS 2(11): 192-196,

November 2021 DOI: https://doi.org/10.37547/pedagogics-crjp-02-11-35

ISSN 2767-3278

(C)2021 Master Journals

Crossref do: 81 Google

Accepted 25th November, 2021 \& Published 30 ${ }^{\text {th }}$ November, 2021

Second, it is not based on abstract school material, but always on the student's world of life, "self-preservation in life."

Third, competency-based teaching focuses more on the student and his or her learning requirements than science-based teaching.

In 1956, the American teacher Benjamin Bloom presented a taxonomy of learning objectives in the field of cognition, in which the following levels are named:

1. Knowledge

2. Understanding

3. Use

4. Analysis

5. Synthesis

6. Evaluation

This normative model should allow teachers to plan lessons purposefully, taking into account the level of aspiration in each case. The current pedagogical process raises many questions about the importance of teacher competence in improving the quality of education. After all, it is important to radically reform the education system in our country, to educate the younger generation to meet world standards. The professional competence of a teacher covers a number of areas. Including professional, personal, spiritual, special, universal. Professional competence, especially today, implies a teacher who is strong in his field, skilled, knows foreign languages, can motivate students, is aware of any socio-political news, innovates and works tirelessly on himself. competence. Professional competence is the acquisition by a specialist of the knowledge, skills and competencies required to carry out professional activities and their application in practice at a high level. LMMitina pedagogical competence means knowledge of the subject, teaching methods and didactics, pedagogical communication skills and competencies, as well as self-development, self-improvement, selflearning. understood the proper combination of methods and means of zini implementation. Personal competence is the formation of such concepts as an active lifestyle of the educator, respect for professional values, responsibility, high self-confidence. This type of competence plays an important role in assessing any achievements and shortcomings of a teacher in the profession. Because the personal component has an individual character, it is connected with human perfection.

In general, it is devoted to the study of the professional competence of the educatorn works are distinguished by the following types. Researcher J. Mannonov commented on this:

- special education ability - a sufficiently high level of professional activity, the ability to design their future professional development;

- socially competent - the ability to work together, cooperate, as well as the methods of professional communication adopted in this book, social responsibility for the results of their professional careers.

An individual who reflects the professional competence of a teacher of vocational education, the interdependence of willpower, intellectual potential, emotional qualities, practical skills, self-management abilities and the level of sociocultural activity of the individual formed on the basis of adjectives.

The formation of the professional competence of a future teacher of vocational education is one of the most difficult issues in the training of teachers. Especially at the current stage of reforms related to the modernization of education, the problem of adaptation to professional pedagogical activity is becoming more apparent. It enriches future vocational education teachers with practical, psychological, 
CURRENT RESEARCH JOURNAL OF PEDAGOGICS 2(11): 192-196,

November 2021 DOI: https://doi.org/10.37547/pedagogics-crjp-02-11-35

ISSN 2767-3278

(C)2021 Master Journals

Crossref do: 81 Google

Accepted 25th November, 2021 \& Published 30 ${ }^{\text {th }}$ November, 2021

methodological, research types, as well as the formation of professional competence of vocational education teachers.

Diagnosis of professional competence Important characteristics of professional formation should include diagnostic, communicative, managerial and projective training groups. The cognitive activity of the educator is determined in many respects by the complexity, dynamics, nonstandardity of the objects studied, the influence of the boundaries that separate social events, their search, uncertainty, which implies observation, the ability to model the interlocutor's inner world. In this case, the characteristics of self-regulation are characterized by the need to constantly improve their knowledge and skills, the ability to strictly coordinate their actions towards other people.

Due to the complexity of the teaching profession, the triad of knowledge, discipline and ethics is crucial for professional practice in daily life. Regular allows the teacher to make decisions in a variety of learning and educational situations that lead to optimal outcomes in the individual situation. This is understood to mean the teacher's attitude and attitude towards the teaching profession. Responsibility and commitment, as well as adherence to certain principles, form the basis for professional activity. Combining many scientific and theoretical knowledge, it is necessary to add the fourth and crucial component of pedagogical professional skills - time management with pedagogical guidelines. The focus is on the teacher's quick decisions, which allow for the coordination of different time intervals so that individual learning can be accomplished with the greatest success, i.e., teaching time (e.g., rhetorically structured o). Instructor's report: inventio, dispositio, elocutio, memoria, pronuntiatio) from the point of view of the prepared teacher, time of individual study (for example, attention, perception, comprehension or misunderstanding, acquisition, practice) and pedagogical communication time.

Well-known scientist Ewald Terhart has three main approaches:

1. "Approach to defining the teaching profession",

2. competency-oriented,

3. Distinguishes the "career-biographical approach".

When it comes to professional skills in primary school, we also think it is permissible to take into account the ideas that have been formed more in Western Europe. The necessary conditions for the professional development of a teacher are freedom and independence in the field of teaching and a high level of responsibility for students in daily school life. This can be achieved in the best elementary or elementary school, as the interdisciplinary classroom system makes lessons flexible over time and allows for methodological variations. That way, the teacher can teach almost independently. Research on the professionalization and expertise of the teaching profession confirms the existence of a high culture of educational professionalism, especially in the early stages.

Pedagogical professionalism in the narrow sense means not only the knowledge base acquired in educational institutions, but also the ability to apply this knowledge in complex and specific working conditions. According to the current state of research and expert conclusions, pedagogical professionalism cannot be fully achieved because the process takes too long on the one hand and cannot be completed due to the framework conditions on the other. However, the teacher agrees with the inconsistency in the education system and is an experts should deal with the requirements professionally. Therefore, basically, it is necessary to interrelate the teacher's point of view and the necessary 
CURRENT RESEARCH JOURNAL OF PEDAGOGICS 2(11): 192-196,

November 2021 DOI: https://doi.org/10.37547/pedagogics-crjp-02-11-35

ISSN 2767-3278

(C)2021 Master Journals

Crossref doi) 81 Google

Accepted 25th November, 2021 \& Published 30 ${ }^{\text {th }}$ November, 2021

condition for making professional efforts.

The term profession is derived from American professional sociology of the 1960s, in which a career model was developed. In order for a profession to be recognized as a profession, the following conditions had to be met:

a) academic education;

b) appropriate socialization;

c) work autonomy.

Since not all criteria apply to the teaching profession, it is not considered a profession, such as the legal profession. The term "professionalism" is used in pedagogy because it focuses on the processes of analytical-reflexive action and the requirements for them. How to define the goal of competency-based learning.

If Schott and AziziGambari's proposal to define competence is followed by a set of tasks proving the existence of competence, the achievement of a particular learning objective can also be proved by solving relevant tasks (performance, skill level).

There is no universal answer to the question of what competence should be available and to what extent for a particular teaching purpose. Instead, there are several different approaches. The purpose of teaching is given when the teacher has no influence on it, i.e., if it is defined, for example, in the form of a curriculum, a legal requirement, or a recognized standard.

A description of the learning objectives by a team of experts.Which competencies should be available and how specific they are for a particular learning goal can lead to different results (see differences in Abitur). In this case, the purpose of training is determined by a free group consisting of recognized and certified experts in the relevant field of science. However, several expert groups may be formed on the topic, leading to different and possibly even conflicting requirements. When it comes to the individual definition of educational goals, in particular, universities face definitions of learning objectives set individually by the relevant professor. Because of the freedom of research and teaching applied there, the professor has the right to do so, but also because of his experience.

Monitoring the success of competency-based learning

If competence is characterized by a set of tasks, control of learning success is accomplished by solving these or similar tasks. However, it is not yet clear which standard will be applied for the next assessment.

The norm of social reference is the relative attitude of the student towards the rest of the group of students. The advantage of this method is that if the student's performance can be easily classified within the group, it can be used quickly and safely. A notable shortcoming is that the social reference norm has a long-term motivational effect on students who are weak and able to learn because they find themselves constantly overworked or difficult enough. know and their value is not directly related to their knowledge. objective performance, but depends on the learning power of the group.

The individual reference norm only takes into account the relative change in student performance. The student is assessed independently of the rest of the group, but requires prior inventory to make the increase in efficiency visible. Due to high-level testing, this standard is often unmanageable in practice.

The objective reference norm describes the difference between the current state of education and the learning objective. It is independent of the study group and the student. However, we conclude that in practice the identification of 
CURRENT RESEARCH JOURNAL OF PEDAGOGICS 2(11): 192-196,

November 2021 DOI: https://doi.org/10.37547/pedagogics-crjp-02-11-35

ISSN 2767-3278

(C)2021 Master Journals

Crossref do: 81 Google

Accepted 25 $5^{\text {th }}$ November, 2021 \& Published 30 ${ }^{\text {th }}$ November, 2021

factual criteria that can be evaluated is not an insignificant problem.

\section{REFERENCES}

1. Mitina L.M. (2004). Psychology of labor and professional development of teachers. - M .: Academy. - $320 \mathrm{~s}$.

2. ST Turgunov and others: "Functional responsibilities of heads of educational institutions in the development of professional competence of teachers." $\mathrm{T}$. 2011y.

3. Sh.Sharipov, N.Muslimov, M.Ismailova: "Pedagogy of vocational education". Methodical manual. - T. $2005 \mathrm{y}$.

4. Dictionary of pedagogical terms. Tashkent. Fan 2008, S. 62.

5. S. Blömeke: ProfessionellesLehrerhandeln. Criteria and actual empirical Erkenntnisseaus der Unterrichtsforschung. Vortrag an der Universität Passau, 11. October 2003.

6. G. Schönknecht: The Development Competence of Competence from Lehrerinnenaus (Berufs-) Biographischer Perspective. 2005, p. 1.

7. Hans Jürgen Apel: Der Lehrer alsRhetor? Lehrkunst and Redekunst. In: H. J. Apel, L. Koch (Hrsg.): ÜberzeugendeRede und pädagogischeWirkung.

ZurBedeutungtraditionellerRhetoric for pedagogical theory and practice. JuventaVerlag, Weinheim / München 1997, pp. 53-80.

8. Otto

Hansmann:

VomZeitmanagementimSchulunterricht. Was Lehrerinnen and Lehrer wissen and könnensollten. Waxmann, Münster u. a. 2009.

9. Ewald Terhart: Lehrerberuf und Professionalität.
GewandeltesBegriffsverständnis - new Herausforderungen. In: W. Helsper, R. Tippelt (Hrsg.): PädagogischeProfessionalität. Beltz, Weinheim u. a. 2011, pp. 202-224, hier 205ff.

10.G. Schönknecht: The Development Competence of Competence in LehrerInnenaus (Berufs-) Biographischer Perspective. 2005.

11. H. Brügelmann: 25 Jahre „Öffnung des Unterrichts": eineZwischenbilanz. In: Die Grundschulzeitschrift. H. 105, 1997, S. 8-11.

12. G. Schönknecht: The Development Competence of Innovation Competence by LehrerInnenaus (Berufs-) Biographischer Perspective. 2005, p. 21. 